\title{
RECENT DEVELOPMENTS IN DEVICES FOR SEISMIC ISOLATION
}

\author{
W. J. Cousins', W. H. Robinson', and G. H. McVerry1
}

This paper was presented at the

Pacific Conference on Earthquake Engineering

New Zealand, November 1991

\begin{abstract}
SUMMARY
Significant extensions to the technology for seismic-isolation were required for three recent applications in New Zealand. The structures isolated were a new Central Police Station in Wellington, a printing press hall built in Petone for Wellington Newspapers Ltd., and capacitor banks at Haywards substation near Lower Hutt. In each case the isolating devices were tested to verify their performance characteristics. This paper presents the results of the testing. The devices were a lead-extrusion damper rated at $250 \mathrm{kN}$ load $\pm 400 \mathrm{~mm}$ stroke, a lead-rubber bearing measuring $609 \mathrm{~mm} \times 609 \mathrm{~mm}$ x $460 \mathrm{~mm}$, and a steel taper-beam damper rated at $10.6 \mathrm{kN}$ load $\pm 200 \mathrm{~mm}$ stroke.
\end{abstract}

\section{INTRODUCTION}

Seismic-isolation has a 15 year history of practical application in New Zealand and has become a routinely considered option for the protection of highway bridges in the most highly seismic regions of the country. The technology is continuing to progress as is well illustrated by three recent applications. The structures isolated were a new Central Police Station in Wellington, a printing press hall built in Petone for Wellington Newspapers Ltd., and capacitor banks at Haywards substation near Lower Hutt. In two cases the isolating devices were much larger, and in one case much smaller, than any previously manufactured in New Zealand. The Wellington Police Station required lead-extrusion dampers that had twice the load and stroke capabilities of their predecessors, the printing press hall required lead-rubber bearings more than twice as large as the previous largest used in New Zealand, and the capacitor banks required comparatively minute steel taper-beam dampers. The design and testing of each of these devices is described below.

\section{$250 \mathrm{kN}$ LEAD-EXTRUSION DAMPERS}

The new Central Police Station for Wellington was classed as an essential facility that should remain functional following a major disaster such as an earthquake, hence was subjected to more stringent seismic design criteria than for a normal building. From amongst the possible types of structure that could be expected to meet the seismic design criteria a base-isolated cross-braced design was selected on the grounds of practicality, cost, and performance [1].

${ }^{1}$ DSIR Physical Sciences, Lower Hutt (Member).
Base-isolation was achieved by mounting the building on $15 \mathrm{~m}$ long flexible piles encased in oversized hollow shafts that were large enough to allow $400 \mathrm{~mm}$ horizontal displacement of the structure. Most of the piles were fixed against rotation at their bases in order to provide an elastic centring force [1].

Damping was provided with lead-extrusion dampers that were pinned between the perimeter base of the building and a basement structure embedded in the ground. Six dampers each rated at $250 \mathrm{kN}$ force were mounted along each side of the building so as to give a total damping force of $3000 \mathrm{kN}$, or 0.035 of the building's seismic weight, in each orthogonal direction [1].

The specifications for the dampers were:

1. stroke capacity: $\pm 400 \mathrm{~mm}$;

2. peak force: $250 \pm 25 \mathrm{kN}$ at an ambient temperature of 15 to $20^{\circ} \mathrm{C}$ and an extrusion velocity of $0.4 \mathrm{~m} / \mathrm{s}$;

3. increase in peak force due to cooling from ambient temperature to $0^{\circ} \mathrm{C}$ : less than $10 \%$;

4. minimum peak force during any one of the first of 5 test cycles of $\pm 250 \mathrm{~mm}$ stroke at $0.4 \mathrm{~Hz}$ and at 15 to $20^{\circ} \mathrm{C}$ : $125 \mathrm{kN}$;

5. average energy absorption over the first three cycles of $\pm 250 \mathrm{~mm}$ displacement at $0.4 \mathrm{~Hz}$ : not less than $70 \%$ of the nominal energy absorption of $250 \mathrm{~kJ}$ per cycle; and

6. dimensions: diameter $200 \mathrm{~mm}$, pin-pin length $2765 \mathrm{~mm}$.

The regime of $\pm 250 \mathrm{~mm}$ at $0.4 \mathrm{~Hz}$ was regarded as a typical operating regime for the dampers during a major earthquake. At this rate the power absorbed by each damper could be as high as $100 \mathrm{~kW}$, giving 1-2 MW for all 24 dampers. 
An orifice-type of design [6] was chosen for the dampers because previous manufacturing experience in New Zealand had been with this type rather than with an alternative "bulge-onshaft" design. Dampers of $150 \mathrm{kN}$ load capacity had been used in the seismic-isolation of the Aurora Terrace and Bolton Street overbridges in Wellington and the Bannockburn bridge in Central Otago [5].

Because the $250 \mathrm{kN}$ dampers were much larger than any previously manufactured, an extensive mechanical testing program was carried out. All were subjected to 6 cycles of \pm $250 \mathrm{~mm}$ displacement at $0.1 \mathrm{~Hz}$ at ambient temperature and one, a prototype, was similarly cycled at $0^{\circ} \mathrm{C}$. Note that the cycling rate was lower than that specified for the typical operating regime, the reason being the limited power rating of the testing equipment that was available. The purchase of a power unit large enough for full rate testing could not be justified given the relatively small rate dependence of lead-extrusion dampers. The formula governing the effect of rate on operating force at rates likely to be encountered during an earthquake is:

$$
F_{1} / F_{2}=\left(R_{1} / R_{2}\right)^{0.03}
$$

where $\mathrm{F}$ is force and $\mathrm{R}$ is rate [6]. A four-fold decrease in rate therefore leads to a $4 \%$ decrease in force.

The load-displacement behaviour of the $250 \mathrm{kN}$ damper was similar to that of the smaller dampers previously tested $[4,5,6]$. Apart from minor perturbations caused by the segmented nature of the lead core, the load remained steady between changes in the direction of displacement (Figure 1), and there was a continuing decrease in load and energy absorption with cycling as the lead in the damper was heated (Figure 2). The average energy absorption over the first three cycles was a little over $80 \%$ of the nominal energy absorption, and the range for all dampers was $75-95 \%$. Cooling a damper to $0^{\circ} \mathrm{C}$ made very little difference to either the shape or size of the hysteresis loops. The variation observed was no greater than the variation from test-to-test at constant temperature.

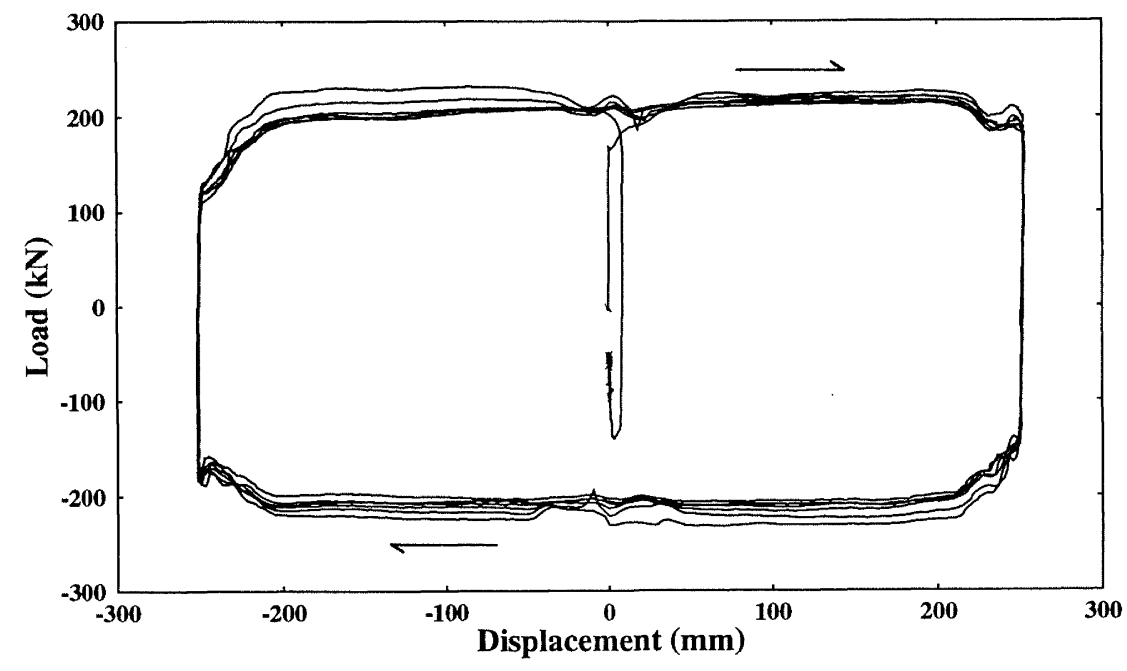

Figure 1: Hysteresis loops for a $250 \mathrm{kN}$ lead-extrusion damper cycled at $0.1 \mathrm{~Hz}$ for 6 cycles.

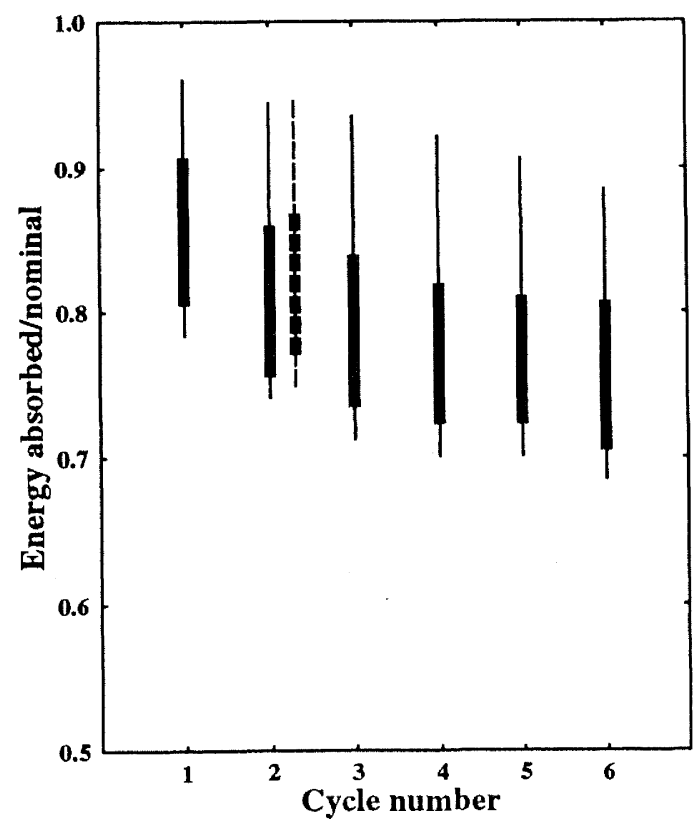

Figure 2: Decrease in energy absorption during cycling: data from twenty-five $250 \mathrm{kN}$ lead-extrusion dampers cycled at $0.1 \mathrm{~Hz}$ for 6 cycles each. Thick lines show standard deviations, thin lines ranges, and dashed lines averages for cycles 1 to 3 . 


\section{LEAD-RUBBER BEARINGS FOR WELLINGTON NEWSPAPERS PRESS HALL}

Lead-rubber bearings were used to base-isolate a reinforcedconcrete printing press hall that was located $20 \mathrm{~m}$ from the Wellington Fault at Petone. Details of the seismic hazard assessment for the site, the dynamic analysis of the structure, and the reasons for selecting lead-rubber bearings as the isolators are given in a companion paper [2].

The layout of structural elements in the press hall set the number of bearings at 38 . Other specifications were: design displacement $\pm 250 \mathrm{~mm}$, post yield period of the isolated structure $2 \mathrm{sec}$ minimum, pre-yield period $0.9 \mathrm{sec}$, and damping force 5 percent of the structural load.

The relatively large design displacement implied a taller bearing than had previously been used in any New Zealand structures if the maximum shear strain in the bearing was to be kept to a satisfactory level. In line with previous practice a maximum rubber shear strain of 0.8 , or overall bearing shear strain of 0.7 , was selected, and this indicated an active rubber thickness of $312 \mathrm{~mm}$. When the thicknesses of the embedded steel plates and inactive rubber at the top and bottom of the bearing were added the total thickness of the bearing became $460 \mathrm{~mm}$. Note that the outermost layers of rubber were considered as inactive because the bearings were intended to be pinned to the structure by means of dowels extending into the outermost steel plates. There were four dowels at each end of the bearing, equally spaced on a radius of $115 \mathrm{~mm}$ from the centre.

Because there was no test data available on the shear and damping properties of such tall lead-rubber bearings, values of shear modulus and damping force had to be assumed for use in calculation of the plan dimensions of the bearings. Extrapolations had to be made from data obtained in many tests on smaller bearings. The basic assumptions used were that the post-yield shear stiffness for the bearings was $\mathrm{Sr}$, and the preyield shear stiffness $10 \mathrm{Sr}$, with $\mathrm{Sr}$ being the shear stiffness of a laminated steel-rubber bearing without a lead core [3]. The indicative bearing dimensions so obtained were $600 \mathrm{~mm} \mathrm{x}$ $600 \mathrm{~mm}$, and hence the largest size of bearing readily available in New Zealand, $609 \mathrm{~mm} \times 609 \mathrm{~mm}$, was selected [8].

For reasons of economy and practicality in manufacture the diameter of the lead plug was set to $105 \mathrm{~mm}$, the same size as for the lead-rubber bearings used to base-isolate the well known William Clayton building [7]. A lead yield stress of $10.5 \mathrm{MPa}$ [3] then implied that 21 of the 38 bearings should have lead cores. Note that the height/diameter ratio for the lead plug was 4.4 which is a little outside the range recommended by Robinson and Tucker [7].

The estimated axial loadings on the bearings varied widely from location to location in the structure, from $300 \mathrm{kN}$ to a high of $2600 \mathrm{kN}$. In order to obtain best performance the lead-rubber bearings were located at the most heavily loaded points, carrying axial loads in the range $1000 \mathrm{kN}$ to $2600 \mathrm{kN}$, and plain elastomeric bearings were used for the remaining 17 locations.

As an additional refinement the elastomeric bearings were designed to have lower axial stiffnesses than the lead-rubber bearings so as to minimise differential settlements during construction. The different axial stiffnesses were obtained by varying the thickness and number of the rubber layers in the bearings, from 24 layers of $13 \mathrm{~mm}$ thickness in the lead-rubber bearings to 20 layers at $16 \mathrm{~mm}$ and 14 layers at $25 \mathrm{~mm}$ thickness in the plain elastomeric bearings. The corresponding axial stiffnesses were $423 \mathrm{kN} / \mathrm{mm}, 289 \mathrm{kN} / \mathrm{mm}$, and 127 $\mathrm{kN} / \mathrm{mm}[8]$

Because the lead-rubber bearings were substantially larger than any previously tested, the previous largest being those for the William Clayton building at $609 \mathrm{~mm} \times 609 \mathrm{~mm} \times 207 \mathrm{~mm}$ high, the first two manufactured were mechanically tested so as to verify the shear and damping properties. The main items of information required were the pre- and post-yield stiffnesses and the effect of variations in the axial load.

The two bearings were mounted in series in a purpose-built test rig and compressed along the axis of the lead plugs to give an initial axial load of either $1000 \mathrm{kN}$ or $2600 \mathrm{kN}$. The axial compressive displacement was then held constant throughout each test. Sinusoidal shear displacements were applied, in the plane of contact of the bearings, with a hydraulic actuator (Figure 3). A cycling rate of $0.1 \mathrm{~Hz}$ was used for all tests. The applied shear displacement and the force required were recorded continuously and the measured force was divided by 2 to give the force pertaining to a single bearing.

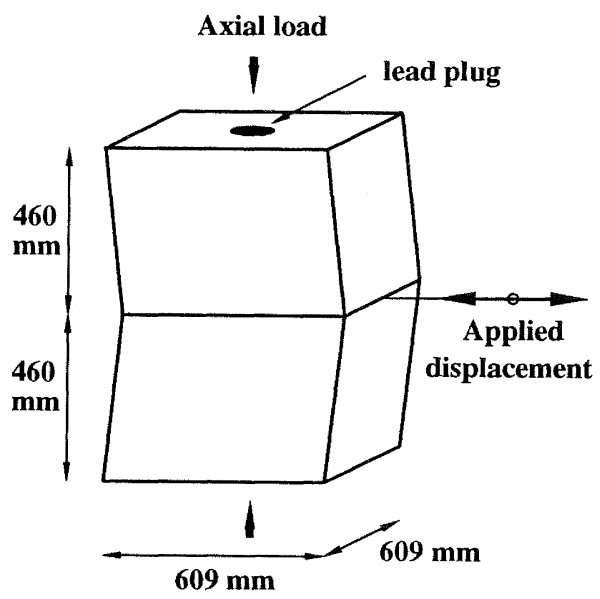

Figure 3: Sketch of two $\mathbf{4 6 0} \mathrm{mm}$ high lead-rubber bearings showing the directions of applied displacements and axial loads.

The resulting hysteresis loops were similar in general form to those obtained previously for smaller lead-rubber bearings $[3,4,5,7,11,12]$. There was a tendency towards increased damping force as either the applied displacement (Figure 4) or the axial load (Figure 5) were increased. The vertical width of the hysteresis loop, and hence the apparent damping force, varied throughout the cycle. Two values for damping force were therefore estimated, (a) at zero displacement and (b) the maximum value from the widest part of the hysteresis loop. Damping forces and absorbed energies are listed in Table 1. 
TABLE 1: Energy absorption and damping force for a single lead-rubber bearing subjected to various axial loads and displacement amplitudes. The bearing measured $609 \mathrm{~mm} \mathrm{x}$ $609 \mathrm{~mm}$ x $460 \mathrm{~mm}$ high and contained a lead plug of $105 \mathrm{~mm}$ diameter. Damping force(a) is the damping force at zero displacement and damping force(b) is the damping force calculated at the widest part of the hysteresis loop.

\begin{tabular}{|c|c|c|c|c|c|}
\hline $\begin{array}{c}\text { Axial } \\
\text { Load } \\
(\mathrm{kN})\end{array}$ & $\begin{array}{c}\text { Displacement } \\
\text { Amplitude } \\
(\mathrm{mm})\end{array}$ & $\begin{array}{c}\text { Peak } \\
\text { Load } \\
(\mathrm{kN})\end{array}$ & $\begin{array}{c}\text { Energy } \\
\text { Absorbed } \\
(\mathrm{kJ} / \mathrm{cycle})\end{array}$ & $\begin{array}{c}\text { Damping } \\
\text { Force (a) } \\
(\mathrm{kN})\end{array}$ & $\begin{array}{c}\text { Damping } \\
\text { Force (b) } \\
(\mathrm{kN})\end{array}$ \\
\hline 2600 & 100 & 165 & 22 & 62 & 62 \\
\hline 1000 & 150 & 230 & 37 & 62 & 66 \\
\hline 2600 & 150 & 238 & 39 & 68 & 72 \\
\hline 2600 & 200 & 262 & 62 & 79 & 89 \\
\hline 1000 & 250 & 291 & 73 & 67 & 88 \\
\hline 2600 & 240 & 295 & 81 & 80 & 97 \\
\hline
\end{tabular}

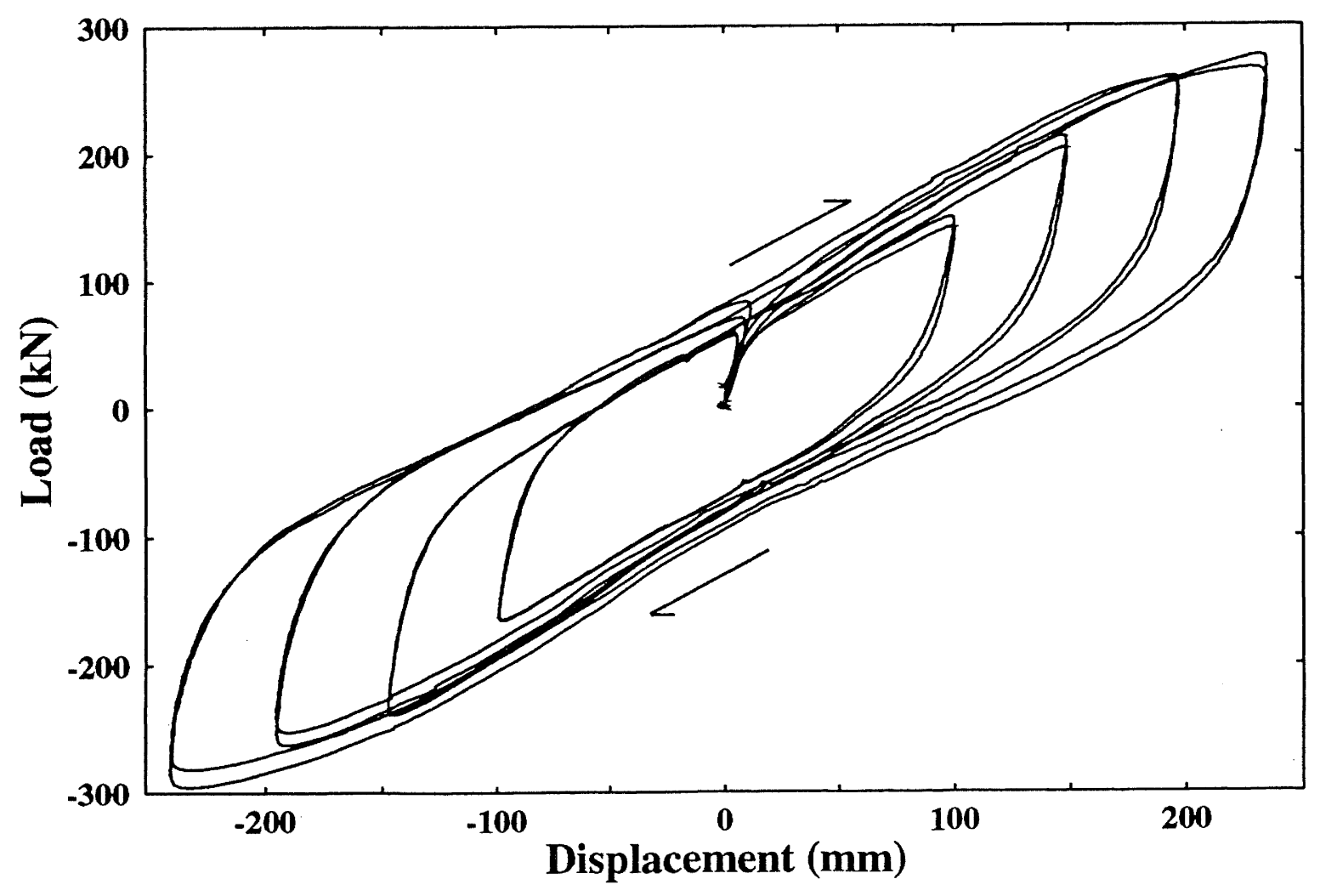

Figure 4: Family of load-displacement loops for a single lead-rubber bearing tested in cyclic shear. The loops are from 2 cycle tests at displacement amplitudes of $100 \mathrm{~mm}, 150 \mathrm{~mm}, 200 \mathrm{~mm}$ and 250 $\mathrm{mm}$, and the initial axial load was $2600 \mathrm{kN}$. 


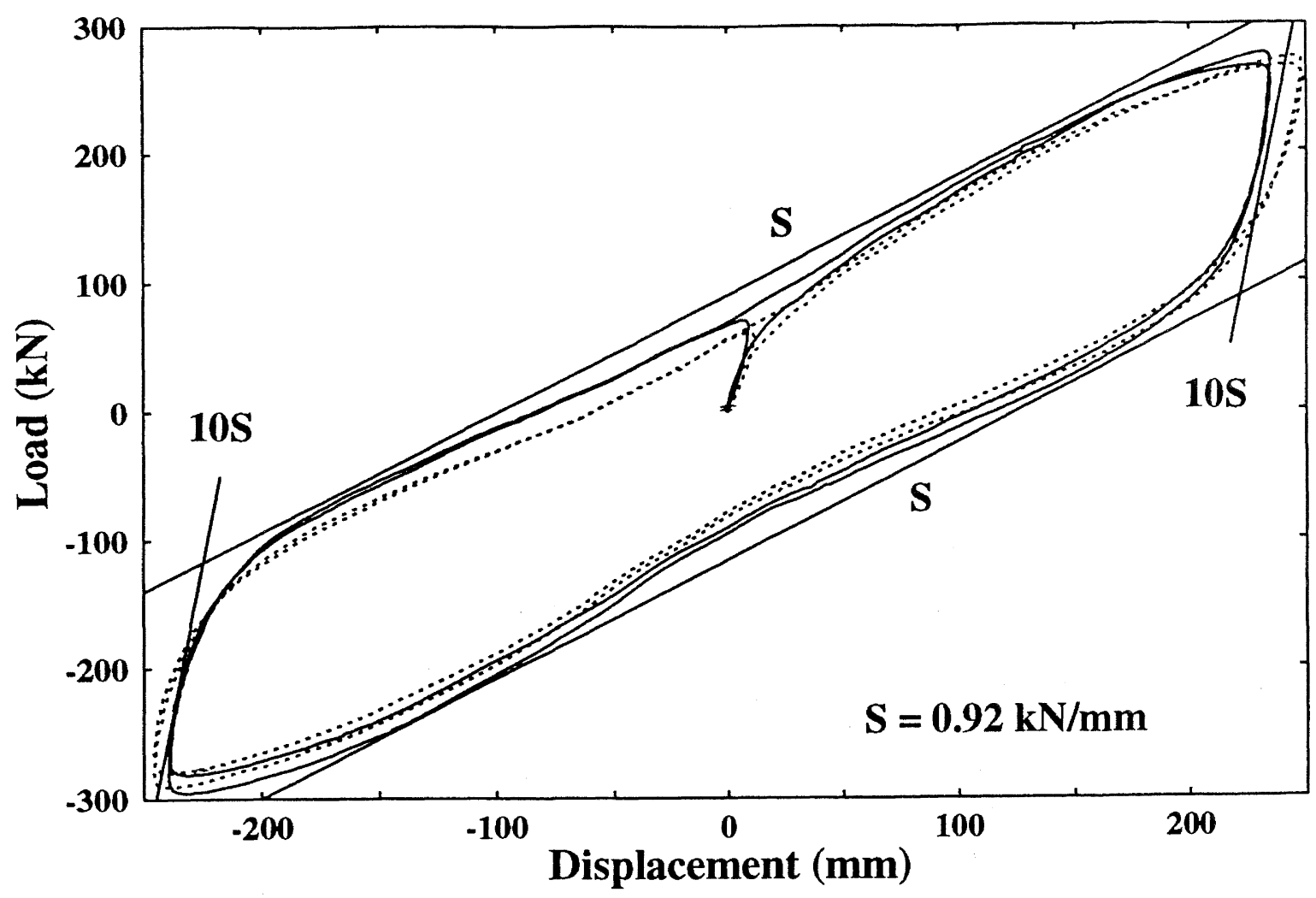

Figure 5: Comparison of hysteresis loops for a single leadrubber bearing tested in cyclic shear under axial loads of $1000 \mathrm{kN}$ (dashed line) and $2600 \mathrm{kN}$ (solid line). Lines of gradient $S$ and $10 S$, where $S$ is the shear stiffness for a single bearing as estimated from the loops, are also plotted to allow comparison with the loops.

On the basis of the above results the post-yield shear stiffness of a single bearing under large displacements was estimated to be $0.92 \pm 0.05 \mathrm{kN} / \mathrm{mm}$, which compares most favourably with the value predicted for a dowel-connected bearing of $0.9 \pm 0.2$ $\mathrm{kN} / \mathrm{mm}[3,8]$. The pre-yield shear stiffness was a little more open to interpretation, but as shown in Figure 5, the suggested value of 10 times the post-yield shear stiffness is not unreasonable.

The predicted damping force based on a $105 \mathrm{~mm}$ diameter lead plug and a yield strength in shear for lead of $10.5 \mathrm{MPa}$ was 90 $\mathrm{kN}$. The peak measured values were close to $90 \mathrm{kN}$ for displacement amplitudes above $150 \mathrm{~mm}$ and axial loads of 1000 and $2600 \mathrm{kN}$. Under other conditions the values were $70-80 \%$ of the expected value. The variation in yield force, expressed in terms of an apparent yield stress in the lead plug, is shown in Figure 6.

The tendency towards lesser damping force at smaller displacements has been observed previously [12] and was attributed to a high height/diameter ratio in the lead plug. This characteristic may be desirable from the point of view of providing a softer response for smaller earthquakes than for large ones.

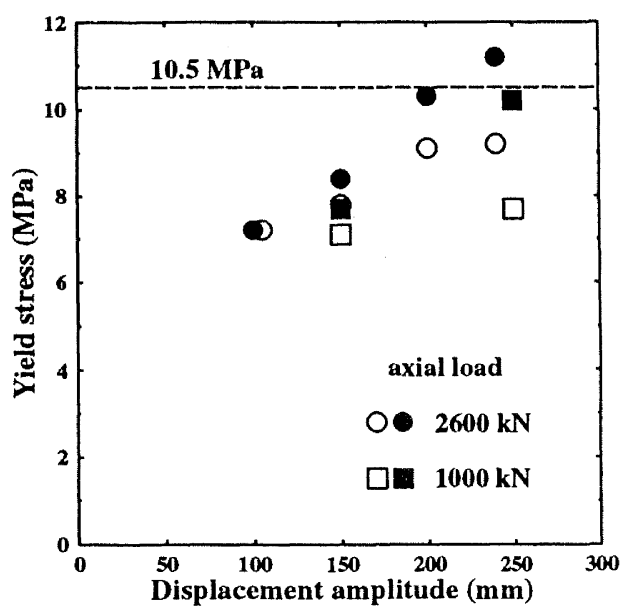

Figure 6: Apparent yield strength of the lead plug in a 460 $\mathrm{mm}$ high lead-rubber bearing as related to displacement amplitude and the axial loading on the bearing. Open symbols show the apparent yield stress at zero displacement and solid symbols the maximum yield stress. The yield strength in shear of high purity lead is $10.5 \mathrm{MPa}$. 


\section{STEEL TAPER-BEAM DAMPERS FOR HAYWARDS SUBSTATION}

Many types of equipment in electricity substations are highly vulnerable to earthquake attack. Electricity supply enterprises in New Zealand are well aware of the earthquake hazard and are taking many preventative measures, including the retrofitting of seismic-isolation to older equipment. The isolation of capacitor stacks at Haywards substation was a recent example of this.

A typical capacitor stack consisted of a group of capacitors mounted within a cross-braced steel cage measuring $9 \mathrm{~m}$ in length, $6 \mathrm{~m}$ in height, and $3.6 \mathrm{~m}$ in width. It weighed 26 tonnes and was supported on 8 ceramic insulators each $1.5 \mathrm{~m}$ high. The ceramic insulators were the components most susceptible to damage from earthquake shaking.

Seismic-isolation was achieved by raising the capacitor stack and its insulators approximately $1 \mathrm{~m}$ off the ground and inserting a horizontal steel frame that was supported on six laminated steelrubber bearings. Damping was provided by two steel taperbeam dampers which were connected between the steel frame and the ground at each end of the capacitor stack.

Normally lead-rubber bearings would have been used so as to provide both isolation and damping within the one economical device, but the relatively low mass of a capacitor stack required a very low value of shear stiffness for the bearings for adequate isolation to be achieved. This, coupled with stability requirements, meant that conventional bearings could not be used and instead the bearings had to be made from layers of rubberencased steel plates separated from one another by small pads of rubber. As a consequence there was insufficient solid material in a bearing to adequately constrain a central lead plug.

Specifications for the taper-beam dampers were derived from dynamic analyses of the isolated structure. The main ones were

1. nominal damping force: $10.6 \mathrm{kN}$

2. displacement capacity: $\pm 200 \mathrm{~mm}$;

3. lifetime: $>70$ cycles at full displacement; and

4. directionality: omni-directional in horizontal plane.

The total damping force required for each capacitor bank was approximately $10 \%$ of the structural weight. This was higher than normally used in seismic-isolation, but was a consequence of the severe seismic design requirements.

A cylindrical type of taper-beam damper seemed most appropriate given the small damping force and the need for omni-directionality. The design procedure was as described by Tyler $[9,10]$ and resulted in a $500 \mathrm{~mm}$ long device of base diameter $45 \mathrm{~mm}$, tapered over the lower two-thirds of its length to a diameter of $31.5 \mathrm{~mm}$ (Plate 1). The peak strain level in the steel beam at full displacement was estimated to be 0.03 which implied a cycling lifetime in excess of 100 cycles [9].

Designing a suitable drive mechanism was the most difficult part of the exercise because a $200 \mathrm{~mm}$ horizontal displacement of the driven end of the damper's shaft was accompanied by a vertical movement of approximately $53 \mathrm{~mm}$ and a rotation of 35 degrees from the vertical axis. After much deliberation a ball-andcylinder arrangement as shown in Figure 7 was selected. A ball diameter of $100 \mathrm{~mm}$ was adequate for the motions involved.
Because there was relatively little prior information on the mechanical performance of cylindrical taper-beam dampers a prototype was constructed and tested. The purposes of the testing were to verify the hysteresis characteristics, to establish the performance at sub-zero temperatures, and to verify the lifetime under full-stroke cycling. The drive cylinder of the prototype was attached to the load-cell of a servo-controlled hydraulic ram, and sinusoidal displacements of up to $\pm 260 \mathrm{~mm}$ were applied to the damper at a rate of $0.1 \mathrm{~Hz}$.

The full test history for the prototype damper was as follows:

- four 2 cycle tests at displacement amplitudes of 50, 100, 150 , and $200 \mathrm{~mm}$ each;

- eight 5 cycle tests at a displacement amplitude of $200 \mathrm{~mm}$, over a period of 20 minutes;

- one 5 cycle test with the damper precooled to -7 degrees $C$;

- one 5 cycle test with the damper precooled to -10 degrees $C$; and

- twelve 5 cycle tests at a displacement amplitude of $200 \mathrm{~mm}$, over a period of 20 minutes, including one cycle at $260 \mathrm{~mm}$.

In general form the hysteresis loops were similar to those previously described for various tapered plate and round bar type dampers $[9,10]$. The damping force, which is the force at zero displacement during large-stroke cycling, was very close to the target $10.6 \mathrm{kN}$ (Figure 8).

There was a moderate increase in force at large displacements due to geometric effects, the effective length of cantilever decreased as the displacement, and the degree of bending in the damper, increased.

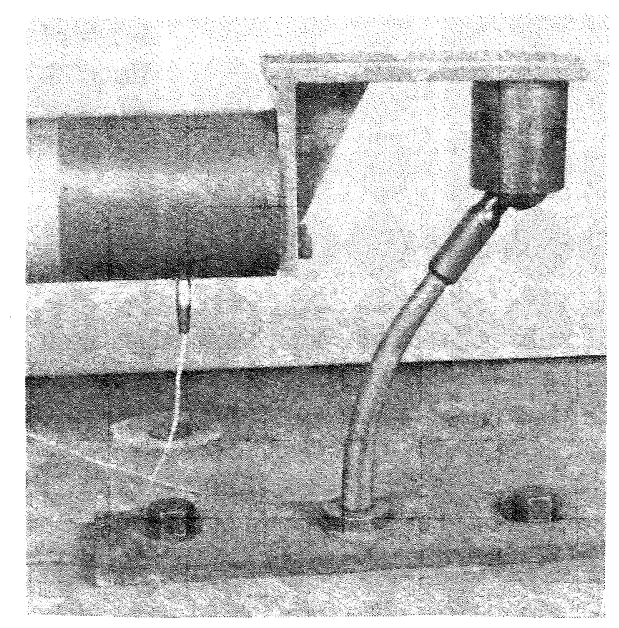

Figure 7: Steel taper-beam damper at full displacement of $200 \mathrm{~mm}$. The cylinder and ball drive mechanism is clearly visible.

At the conclusion of the testing the damper appeared to be in good condition and was absorbing nearly as much energy per cycle as at the start of testing. The apparent reduction in energy absorbing capacity over the 112 cycles was only $10 \%$, but this may well have been at least partly a temperature effect because (a) there was very little difference between the energies absorbed during full stroke cycles 1,2 and 53,54 , for which the initial damper temperatures were similar, and (b) the tests with the damper precooled showed slightly elevated levels of energy absorption (Table 2). 


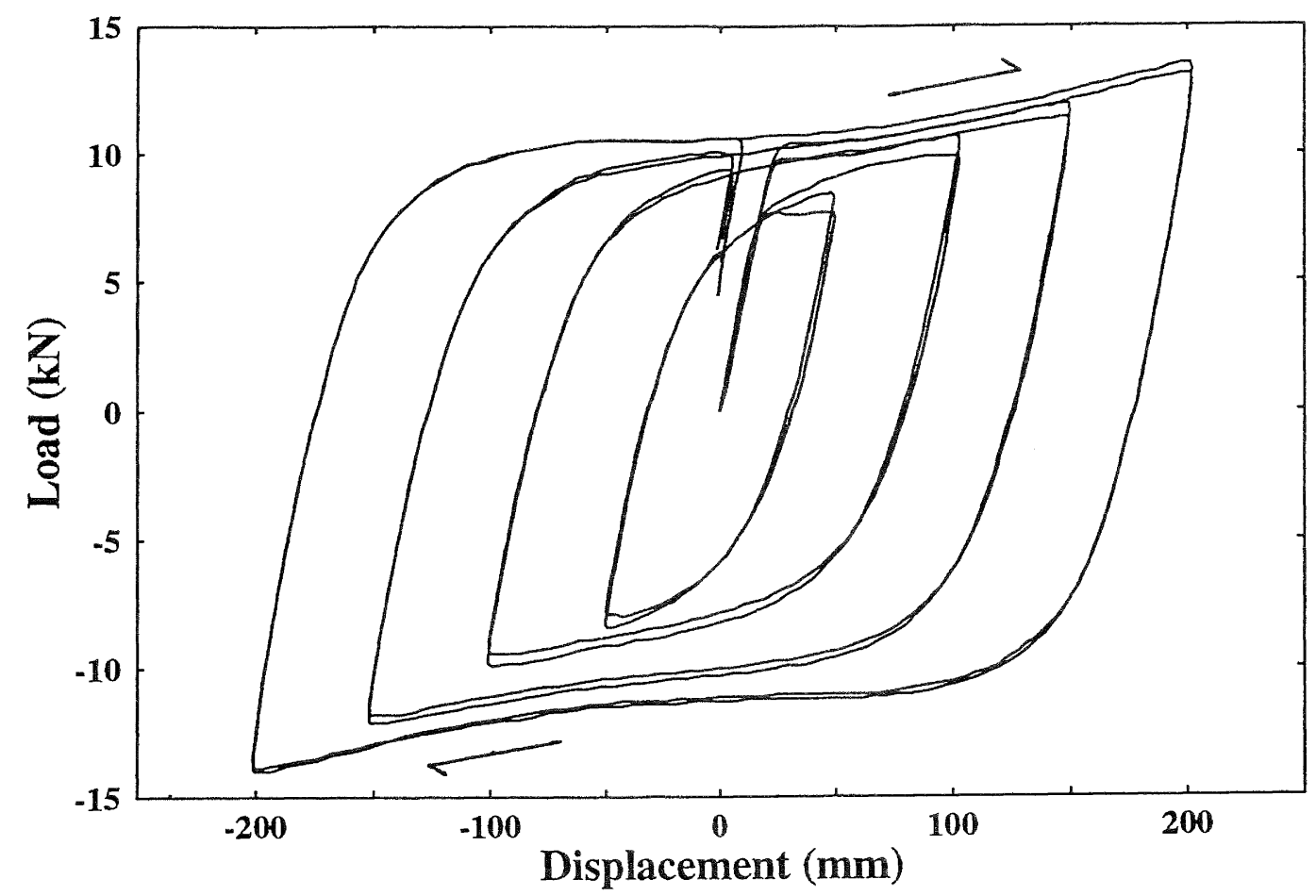

Figure 8: Family of load-displacement loops for a $10.6 \mathrm{kN}$ steel taper-beam damper. The loops are from 2 cycle tests at displacement amplitudes of $50 \mathrm{~mm}$, $100 \mathrm{~mm}, 150 \mathrm{~mm}$ and $200 \mathrm{~mm}$.

TABLE 2: Damping force and energy absorption data for a nominal $10.6 \mathrm{kN}$ steel taper-beam damper tested under various conditions. The initial damper temperature is the temperature of the damper at the commencement of a 5 cycle test. The peak damping force is the average magnitude of the highest positive and negative forces measured during a cycle, and the nominal damping force is the average magnitude of the positive and negative forces at zero displacement.

\begin{tabular}{|c|c|c|c|c|c|}
\hline $\begin{array}{l}\text { Displacement } \\
\text { amplitude } \\
(\mathrm{mm})\end{array}$ & $\begin{array}{c}\text { Initial } \\
\text { Damper } \\
\text { Temp. } \\
\left({ }^{\circ} \mathrm{C}\right) \\
\end{array}$ & $\begin{array}{c}\text { Full } \\
\text { Stroke } \\
\text { Cycle } \\
\text { Number } \\
\end{array}$ & $\begin{array}{c}\text { Nominal } \\
\text { Damping } \\
\text { Force } \\
(\mathrm{kN}) \\
\end{array}$ & $\begin{array}{c}\text { Peak } \\
\text { Force } \\
(\mathrm{kN})\end{array}$ & $\begin{array}{c}\text { Energy } \\
\text { Absorbed } \\
(\mathrm{kJ} / \text { cycle })\end{array}$ \\
\hline 50 & 20 & $"$ & 6.0 & 8.5 & 0.8 \\
\hline 100 & " & $"$ & 8.7 & 10.3 & 2.6 \\
\hline 150 & $"$ & $"$ & 10.2 & 12.0 & 4.9 \\
\hline 200 & 30 & 1,2 & 10.9 & 13.8 & 7.7 \\
\hline 200 & -7 & 43,44 & 12.0 & 15.7 & 8.1 \\
\hline 200 & -10 & 48,49 & 11.4 & 14.7 & 7.9 \\
\hline 200 & 20 & 53,54 & 10.8 & 14.0 & 7.5 \\
\hline 200 & $"$ & 78,79 & 10.0 & 13.1 & 7.0 \\
\hline 200 & $>130$ & 108,109 & 10.2 & 13.5 & 7.0 \\
\hline
\end{tabular}


The drive mechanism showed earlier degradation with extended cycling than did the damper itself. Initially both the drive ball and the driving cylinder were made from mild steel that had not been specially heat treated, and the lubricant was a conventional bearing grease of good quality. After 46 cycles of testing the contacting surfaces of the ball and the cylinder were badly scored and the hysteresis loops had become quite irregular. However, when the drive ball was casehardened and a molybdenum-rich lubricant with antiscuffing properties was used the drive components showed only minor wear after 70 cycles. Hence the lifetimes are:

-drive system $>70$ full stroke cycles

-damper element $>112$ full stroke cycles.

Note also that because of the unidirectional nature of the testing the wearing of the drive mechanism was concentrated over small regions of the ball and cylinder. In any real earthquake the displacements would tend to be orientated throughout the horizontal plane and hence the lifetime of the drive mechanism can be expected to greatly exceed 70 cycles.

A stroke of $\pm 260 \mathrm{~mm}$ was imposed for one cycle without catastrophic failure of either the damper or the drive mechanism, indicating that a degree of overload beyond the nominal full stroke could be tolerated.

The peak strain in the damper was estimated to be 0.03 , and as might be expected from repeated cycling to this level the damper grew in length over its active region. After 70 full stroke cycles the increase in length over the $330 \mathrm{~mm}$ long tapered region was $5 \mathrm{~mm}$, and after 112 cycles it was $7 \mathrm{~mm}$.

\section{CONCLUSIONS}

The test results given above have significantly extended the size range of devices available for seismic-isolation purposes. Each of the three devices performed as predicted by extrapolations from previous test data.

\section{REFERENCES}

1. Charleson, A.W., Wright, P.D. and Skinner, R.I. 1987. "Wellington Central Police Station, base isolation of an essential facility", Proceedings of Pacific Conference on Earthquake Engineering, New Zealand, 5-8 August 1987, Vol 2, New Zealand National Society for Earthquake Engineering: 377-388

2. Dowrick, D.J., Babor, J., Cousins, W.J. and Skinner, R.I. 1992. "Seismic isolation of a printing press in Wellington, New Zealand". Bull NZNSEE, Vol. 25 No.3, September.

3. Robinson, W.H. 1982. "Lead-rubber hysteretic bearings suitable for protecting structures during earthquakes", Earthquake Engineering and Structural Dynamics 10(4): 593604

4. Robinson, W.H. and Cousins, W.J. 1987. "Recent developments in lead dampers for base isolation", Proceedings of Pacific Conference on Earthquake Engineering, New Zealand, 5-8 August 1987, Vol 2, New Zealand National Society for Earthquake Engineering: 279-283
5. Robinson, W.H. and Cousins, W.J. 1988. "Lead dampers for base isolation", Ninth World Conference on Earthquake Engineering, August 2-9, 1988, Tokyo-Kyoto, Japan (Vol VIII): 427-432

6. Robinson, W.H. and Greenbank, L.R. 1976. "An extrusion energy absorber suitable for the protection of structures during an earthquake", Earthquake Engineering and Structural Dynamics 4(3): 251-259

7. Robinson, W.H. and Tucker, A.G. 1981. "Test results for lead-rubber bearings for Wm Clayton building, Toe Toe bridge, and Waiotukupuna bridge", Bulletin of the New Zealand National Society for Earthquake Engineering 14(1): 21-33

8. Skellerup Rubber Manufacturing Ltd., 1989. "Skellerup elastomeric bearings, pads and strips to BE 1/76"

9. Tyler, R.G. 1978. "A tenacious base isolation system using round steel bars", Bulletin of the New Zealand National Society for Earthquake Engineering 11(4): 273-281

10. Tyler, R.G. 1978. "Tapered steel energy dissipators for earthquake resistant structures", Bulletin of the New Zealand National Society for Earthquake Engineering 11(4): 282-294

11. Tyler, R.G. and Robinson, W.H. 1984. "High-strain tests on lead-rubber bearings for earthquake loadings", Bulletin of the New Zealand National Society for Earthquake Engineering 17(2): 90-105

12. Tyler, R.G. and Robinson, W.H. 1985. "Tests on leadrubber bearings", US-NZ Workshop, Seismic Design of Bridges, San Diego, California. 